\title{
DES MOINES CONFERENCE REDUCES AREA
}

\author{
By the REv. R. E. HARVEY
}

$\mathrm{V}$.

MORE INTENSIVE CulTivation-1872-1900

The year of Grace 1872 was epochal for the Methodist Episcopal church in western Iowa, marked not only by the first presence of her lay delegates in the General conference held in May of that year, but by actions of that body looking toward promotion of western Methodist interests generally. One of these was the location of a book depository, a branch of the denominational publishing house, in Council Bluffs. Another provided more adequate supervision of the work in the new northwest, by assigning to residence, somewhere in the Missouri Valley, of the Rev. Edward G. Andrews, one of eight new accessions to the board of bishops, in furtherance of whose mission, the imperial domain of Des Moines Conference was divided by setting off a new administrative unit called the North West Iowa conference.

Although no mention of such impending change found place in the 1871 Journal of Des Moines conference, off the record discussion of the possibility must have occurred at that time, as appears between the lines of a paper adopted on the second day of the 1872 session, held at Chariton, September 25-30, Bishop Andrews presiding, to-wit:

"Resolved, 1. That, notwithstanding our united opposition to a division of our conference by the late General conference, inasmuch as our delegation did at last yield to our brethren in the north, by submitting to a division, we will cheerfully and unitedly acquiesce in such division."

\footnotetext{
1 Earlier articles of this series appeared in THE ANNALs OF IOWA, History of the Des Moines Conference, Vol. XXV, pp. 192-228; Des Moines $M$. E. Conference Growth, Vol. XXV, pp. 282-312; War Years Des Moines M. E. Conference, Vol XXVII, pp. 44-61; Imperial Expansion of $M$. E. Church, Vol. XXVII, pp. 119-150. Sources of information stated in the introduction to the first article are the same herein with exception that much of the data herein concerning years 1872-1887 was obtained from the individuals, and since latter year the writer was a participant in events.
} 
"Resolved, 2. That our thanks are justly due to our delegation, and particularly to that one on the Committee on Boundaries, for his wise and safe management of our boundary 'lines', causing them to 'fall to us in pleasant places and giving us a goodly heritage':"

The said lines, officially described, ran as follows ${ }^{2}$ : "The Des Moines Conference shall include that part of the state of Iowa west and south of the following lines: Beginning at the southeast corner of Wayne county; thence north to the south line of Marshall county, leaving Knoxville in Iowa conference and Monroe charge in Des Moines conference; thence west to the south-east corner of Story county; thence north to the north-east corner of Story county; thence west to the northeast corner of Crawford county; thence south to the north line of township eighty-three; thence west to the east line of Monona county; thence south and west on the line of Monona county to the Missouri river."

The limits thus contained twenty-seven full counties and halves of three others, constituting two-sevenths of the state's area, or about sixteen thousand square miles, supporting at that time a population of 325,000 , of whom something over 17,000 were Methodist communicants, with an equal number of non-members enrolled as Sunday school attendants, to which might probably be added as many more adherents.

These worshippers were distributed among 108 parishes, ranging in membership from Exira with thirtyseven, to Indianola with 389 , and worthy of note, is, that, with the exception of Indianola, the largest number were found in rural communities. The leading church in Des Moines, Fifth street, for example, listed 203 members, and was far exceeded by ${ }^{\circ}$ two country circuits adjacent to the city. Many of the county seat churches were likewise largely outnumbered by nearby charges, a condition long ago quite generally reversed. Then as now, how-

2Methodist Episcopal Discipline of 1880 ; p. 227, Par. 410. As no change of boundaries occurred in the interval, there can be no doubt that these were the lines prescribed in 1872 . 
ever, there was more money available for church purposes in the larger centers of population, as manifested by the succeeding exhibit of ministerial support.

Fifth street, Des Moines, $\$ 1,600.00$; Indianola, $\$ 1,-$ 500.00; Council Bluffs, First, $\$ 1,325.00$; Wesley-Des Moines, $\$ 1,200.00$; Bedford, Centenary-Des Moines and Osceola, $\$ 1,000.00$ each; Glenwood and Sydney, $\$ 950.00$ each; Ames, Red Oak, Winterset, each $\$ 900.00$; Afton, Atlantic, Boone, Boonesboro, Clarinda, Council Bluffs Second, Council Bluffs Circuit, Jefferson, Monroe and Nevada, each $\$ 800.00$; Fremont (a circuit in that county) $\$ 770.00$; Panora, $\$ 730.00$; Altoona, Chariton, Garden Grove, Guthrie Center, Lawrenceburg, Malvern, Missouri Valley, and Norwalk, each $\$ 700.00$; Dunlap, Mount Ayr, Palmyra, Winterset circuit, each $\$ 650.00$; Tabor, pledged $\$ 625.00$, but unfortunately fell considerably short; eighteen charges were rated at even $\$ 600.00$ each; twenty at $\$ 500.00$ to $\$ 580.00$; ten at $\$ 400.00$ to $\$ 495.00$; six stood at $\$ 300.00$ to $\$ 375,00$; seven at $\$ 200.00$ to $\$ 285.00$; Des Moines City Mission pledged $\$ 150.00$ and paid every cent of it, receiving $\$ 100.00$ missionary stipend in addition; eleven charges, for unstated reasons made no report either financial or numerical; and two presiding elders gave their salary subject the same silent treatment; another gave his promised "support" as $\$ 975.00$, but left the "Receipts" space blank. Three who gave full reports including salary, house rent and travelling expenses, were pledged respectively, $\$ 1,400.00$, $\$ 1,141.00$, and $\$ 1,100.00$; receiving in the same order, $\$ 1,220.00, \$ 965.00$, and $\$ 870.00$. The total ministerial budget for that year, $1871-2$, was $\$ 56,580.00$, which was paid, eighty-four cents on the dollar; the sixteen percen $\imath$ deficit falling mainly upon those least able to spare it, those in the lower salaried positions. The beneficient principle of "Brotherly Sharing" then exhibited so different than in this more generous day when the "strong" help bear the infirmities of the "weak," a development of a far and undreamed of future. 
These 108 parishes possessed 110 houses of worship and 64 parsonages, all valued at $\$ 327,000.00$, eight churches and one parsonage being newly erected that year; while the debt encumbrances of $\$ 15,425.00$ equalled less than four and one-half per cent of the total values, setting a model for all succeeding church financiering, 308 Sabbath schools were maintained at a cost of $\$ 4$,106.00 ; and $\$ 3,910.36$ in free will offerings were made to the general church boards for Missions, Church Extension, Tracts, Sunday Schools, Freedman's Aid and education.

\section{ACCessible Territorial Area}

The territory thus occupied and equipped was bisected east and west by the Burlington, Rock Island, and Northwestern railway systems, with the Milwaukee pressing close after them, all four sprouting feeder radii right and left; while along the eastern edge the Des Moines Valley line replaced completely the very unreliable water traffic on that stream; so that even the most remote communities were not over a days drive from transportation facilities. Altogether, the newly aligned Des Moines conference constituted such a "Goodly Heritage" that the heirs and assigns thereof for three score years steadily resisted all proposals for a readjustment of their "lines" on the north and east.

Having duly considered the possibilities of their contracted area, the conference proceeded to regular business, with a few new wrinkles added. A recent provision pertaining to the ordination of missionary candidates was applied in the case of Brenton $\mathrm{H}$. Badley, enabling him to return to India as a full-fledged elder, without awaiting the expiration of the four years in the conference course of study, to the great advantage of himself and his work. Having tasted with relish the flavor of lay participation in church councils, a request was voted that each district should send three laymen to the $\mathbf{1 8 7 3}$ session, one of whom should sit in the bishop's cabinet, the reactions to which will be noted. 
The Preacher's Aid society, having made a beginning toward accumulating an endowment fund, now proceeded to incorporate for legal management, inserting a proviso that the earnings should be added to the principal until the whole totaled $\$ 10,000.00$, after which the income should be contributed to relief of conference claimants ${ }^{3}$; also a provision that none of the funds should be invested either in United States or state bonds, or loaned on real estate mortgage at a less rate than seven per cent. This reads oddly in the present era of microscopic investment returns, but during most of the period under consideration, loans on real estate drew ten per cent, with plenty of takers at that exorbitant rate, and short time loans commanded three per cent a month, paid in advance.

Enthused at the assignment of a bishop to the new north west, a committee was appointed to solicit monies and purchase resident property in Council Bluffs. A board of trustees was elected to care for the same, to which board all the Methodist conferences in Iowa and Nebraska were invited to appoint members and, incidentally, share in the cost of the undertaking. Appreciative resolutions were adopted relative to the proposed book depository, for the management of which the Rev. Joseph Knotts, retiring presiding elder of Council Bluffs district, and James Wright, M.D. of Des Moines, were nominated as agents.

The committee on education brought in a glowing report of the past successes and future prospects of Simpson Centenary college; attendance was increasing; tuition and other receipts balanced expenses; accruing endowment funds stimulated hope that the goal of $\$ 100,000.00$ might be speedily realized; two of the alumni were entering conference, while a third, promised a greater measure of future usefulness by seeking more complete preparation in Garrett Biblical Institute.

"Conference Claimants" were retired ministers, widows and younger orphans of deceased ministers, and such ministers as through illness or accident might be adjudged necessitous cases. So far did this fall short of a regular pension system that all grants were based upon actual necessity; rendering most trying the task of the conference stewards, dispenser of relief funds, owing to invariable shortage of resources. 
As to spiritual interests, although the district reports could not make great mention of extensive revival movements, the record of 918 conversions from among the Sabbath school attendants certainly indicated a healthy growth.

\section{LOSS OF A DYNAMIC LEADER}

Tidings came on the third day of the session, of the death at the age of 89 , of the Rev. Peter Cartwright, one whose passing constituted another sort of epoch, in that during a gospel ministry of seventy years, he had associated intimately with all the leading figures of the first century of American Methodism and whose name was written large on the frontiers of the old west, all the way from Mississippi to Wisconsin; and who also might justly be called the Founding Father of Iowa Methodism, since the missionaries who planted both our initial fields, Dubuque and Burlington, were sent by him from his Quincy District on the Illinois shore. Moreover, to his superb qualities as circuit rider and camp meeting evangelist, he added executive talents that kept him fifty years in the sub-episcopal office of presiding elder, and ecclesiastical statesmanship that in twelve quadrennial general conferences projected his influence into church polity and legislation; while an unfailing store of eccentric wit and humor, accompanied by absolute mental and physical fearlessness, with literary ability-of sorts-had made him a national legendary figure even before his hair was gray.

All in all, the departure of the Rev. Peter Cartwright must have seemed like the severing of the last tie connecting the glamorous, heroic, romantic infancy of the church with its sage maturity, and his funeral, at the Illinois home, occurring 'as it did at an hour already chosen for a solemn communion service and the reception of candidates in full membership, was recognized by resolutions and oratory linking past, present and future as by a golden chain. 
The next.day there was introduced, as a visitor, a very recent colleague, the Rev. Bennett Mitchell, who, functioning for the third time as charter member of a new conference, was acting as commissioner from North West Iowa to secure equitable adjustment of church extension, and funds of the undivided Des Moines conference; of which $\$ 1,000.00$ of the first and $\$ 200.00$ of the second were allotted to the departing brethren. It also appears probable that they received farther consideration from the mission board, since of $\$ 1,100.00$ of missionary aid granted to eighteen charges south of the dividing line in 1871, this year there was but $\$ 800.00$ allowed to thirteen charges, leaving it fair to assume that the difference was allocated to the newer and needier field.

Monday morning, September 30th, after all business was completed, Bishop Andrews conducted exercises of scripture reading, song and prayer, briefly addressed the assembled company, and answered Question XXI of the conference program, "Where are the preachers stationed this year?" by reading out the subjoined list, in which, as once before, the writer has taken the liberty of starring the names of such as he later enjoyed the privilege of knowing personally.

\section{Des Moines District}

C. C. Mabee*, Presiding Elder, Post Office, Des Moines, Iowa

Des Moines Fifth street

P. P. Ingalls

Des Moines Centenary.

L. M. Walters

Des Moines Wesley chapel......

J. H. Swope

Des Moines Mission.

..S. N. Matheny*

Des Moines Circuit.

A. Badley

Polk City
Saylorville. To be Supplied

Altoona V. G. Boynton

Prairie City H. M. Sexton Prairie City Ct.....D. O. Stuart* Monroe T. McK. Stuart*

Colfax D. Shenton* Greencastle. To be supplied

De Soto

Adel. J. W. Todd

Waukee. F. M. Slusser

Cambridge
..D. Thompson* I. T. Miller 


\section{INDIANOLA DISTRICT}

J. G. Eckles, Presiding Elder, Post Office, Indianola, Iowa

Indianola A. C. Williams

Ohio R. J. Davis Indianola Circuit....J. C. Eckles Pleasantville.......J. J. D. Scoles Palmyra. S. R. Ferguson Carlisle E. Kendall Liberty ...G. Clammer, G. S. Wharton Winterset J. F. Goolman Winterset Ct.....S. W. Milligan*

St. Charles Newbern

Columbia.

Norwalk..J. A. Smith, S. D. Fry

A. Burns, President of Simpson Centenary college and member of Indianola Quartely Conference.

\section{Chariton District}

J. M. Conrad", Presiding Elder, Post Office, Osceola, Iowa

Chariton H. H. O'Neal*

Chariton $\mathrm{Ct}$.

B. B. Kennedy

Russell..To be supplied by Wood Osceola D. McIntyre* Woodburn M. H. Martin Caledonia To be supplied New York..W. F. Bartholomew * Leon Simpson Huyer
Pleasanton W. S. Thorn* Garden Grove. Decatur City E. H. King ...W. S. Hooker*, P. Vollmer* Mount Ayr Corydon. M. Miller* G. P. Bennett Corydon Circuit......W. M. Welch Lineville. To be supplied

\section{CORNING DISTRICT}

U. P. Golliday*, Presiding Elder, Quiney, Iowa

Corning-

Afton T. S. Berry Afton Circuit

P. St. Clair

Supplied by W. F. Mark Creston and Lenox

W. H. Rees

L. McK. Campbell*

Goshen J. W. Bott* Mormontown........To be supplied Bedford William Hayes Harmony J. T. Hughes*
Hawleyville. A. Kern Clarinda A. , Brown* College Springs

Red Oak Villisca W. J. Beck* Brooks R. M. Smith ..To be supplied by J. A. Lovejoy*

\section{Quincy}

To be supplied by F. R. Morey

\section{Councrl Bluffs District}

B. Shinn*, Presiding Elder, Post Office, Council Bluffs, Iowa Council Bluffs, First Ch......... P. F. Bresee

Council Bluffs, 2nd Ch. Council Bluffs Circuit F. Harris* F. Plumb Glenwood J. C. R. Layton
Malvern....R. Daly, I. Kelly Sup. Emerson. E. W. Sage Tabor T. P. Newland* Fremont City........W. F. Laidley Walnut. S. Farlow* Missouri Valley....I. M. O'Flyng* Woodbine. W. E. Hamilton* 
Dunlap. J. Van Scoy

Denison G. C. Waynick

Little Sioux and Magnolia.

J. W. Adair*

H. Delong*

Council Bluffs city missionary

C. Hover.

Agent Ch. Ex. Soc. and mem. Hamburg.

Sidney.

C. W. Blodgett*

J. B. Hardy

Second Council Bluffs Charge, quartely conference

Shenandoah.

J. P. Evans*

Boonseoro District

M. D. Collins*, Presiding Elder, Post Office, Boonsboro, Iowa

Boonsboro Samuel Jones

Boonsboro Circuit ...C. H. Lakin

BooneW. C. Martin*

Ames A. Wilson

Ontario be supplied

Nevada J. Fegtley

Iowa, Center E. W. Brady Ridgreport J. W. Snodgrass*

Xenia

Ogden To be supplied

Perry. S. Snyder

Grand Junction....To be supplied Jefferson

Scranton

Carroll J. A. Ward

Carrollton To be supplied To be supplied T. Hamilton

E. M. H. Fleming*, Presiding Elder, Post Office, Atlantic, Iowa Atlantic. A. J. Andres* Grove City.

Milford Harlan

L. W. Archer*

To be supplied by A. C. Smith Exira. G. W. Saint

Casey Levi Park Guthrie Center......Chas. Ashton Stuart. B. Durfee*

Panora J. Hestwood*

Dexter James Lisle Greenfield. M. Mitchell Fontanelle. M. Sheets

Lewis W. Abraham* Wilson. J. N. Page, supply ....William Armstrong, supply R. W. Thornburg, transferred Northwestern Iowa conference

D. R. Latham, transferred to Michigan conference

S. E. Willing, transferred to Wisconsin conference

A. Burries, transferred to Nebraska conference

B. H. Badley, Missionary to India.

And with the Episcopal benediction resting upon them, the Des Moines conference departed to consolidate their narrower but still ample bailiwick. The records of their achievements will be henceforth presented topically, as better suited to the rapid expansion of the church and her activities, as indicated by occasional summaries; while outstanding events and individuals will receive representation.

The proposed location of a residence for Bishop Andrews in Council Bluffs was taken up so energetically 
by the committees appointed, that they lacked a mere one thousand dollars of the cash in hand required when the project was halted by the bishop's refusal to accept the property selected, and finally declined living in Council Bluffs at all. The funds collected were returned to the donors and no further effort was put forth on this line. In 1880, when Andrews was reassigned to Washington, D.C. and Bishop John F. Hurst succeeded him here, an effort to procure for him a residence in Des Moines failed for lack of interest outside the city. In 1884 the Missouri Valley was dropped from the episcopal residential schedule, and Des Moines remained bishopless until Unification of American Methodism in 1939; since then the area has been limited to Iowa, and an eligible mansion secured, which seemingly insures the continuation of present arrangements for an indefinite future.

The promised book depository fared no better. A half page advertisement in the Journal for 1873 announced its opening with a suitable stock in trade, also mentionnig the launching of a monthly periodical The Council Bluffs Christian Advocate, Rand and Knotts, publishers, with which the enterprise drops out of sight. The agent, the Rev. Joseph Knotts, who had superannuated in 1872 , was continued in that relation until 1878 , when at his own request, and with expressions of esteem, he was granted a location, and so disappears from our view.

\section{A WOMAN's ORganization LAUNCHED}

A better report can be made concerning the Woman's Foreign Missionary Society, which originating as a voluntary movement was recognized by the General conference of 1872. To this Des Moines Methodist women contributed $\$ 49.75$ that same year, multiplying this three and one-half times in 1873, when they were first allotted space in the statistical tables, while a highly laudatory committee report hailed the advent of this new detachment of the church militant. That initial offering mounted almost annually in varying ratio, reaching in 1900 the magnificent sum of $\$ 8,947.00$, while through the 
years a succession of devoted young women have volunteered for overseas duty in the Master's cause. Eight years subsequently to the formation of the foreign work, the Woman's Home Missionary society was accredited, although not taking form in this conference until 1883 . Their reported contributions for 1884 was a timid $\$ 20.00$, but nothing daunted these home-building women persevered, and although never overtaking their sister-and possible rival-group, their 1900 contribution was $\$ 1$,193.00, a thirty-five per cent gain over 1899; while the absorption of the Deaconness movement into their agenda in 1893 gave the society prestige entirely out of proportion to its financial returns. This then new departure in Methodistic polity was inaugurated here in 1892 by the employment of a deaconess by First church, Des Moines', speedily followed up by organization of the Deaconess Home association, with established headquarters, and the institution of plans for work in three city parishes. Following the transfer to the jurisdiction of the W.H.M.S. came the founding of Bidwell Deaconess Home, out of the proceeds of a bequest made by the generous layman for whom it was named. By the century end the deaconess work was firmly established with classes of candidates receiving thorough training, and systematic activities carried on in Des Moines and Boone.

Meanwhile the interdenominational and international movement of the Woman's Christian Temperance Union was enlisting large numbers of Methodist women in its local auxiliaries, while W.C.T.U. speakers and conventions were given right of way in Methodist pulpits and churches; all of which contributed not a little to putting the Methodist church in the front ranks of the battle against booze, and in which the conference participated with ringing resolutions at every session, utterances made especially drastic during election campaigns. That such were sometimes unfortunately worded, provoking unfavorable reactions, was perhaps only human; that they bolstered church morale is also undoubtedly true,

'Annual report of presiding elder of Des Moines district for 1892. 
combining with stirring sermons and addresses to maintain high levels of public sentiment. While no such tragedy as the murder of the Rev. George Haddock in Sioux City occurred in this part of the state, yet it could easily have happened, but for the act of a zealous preacher, stationed in a saloon ridden community, who in defending himself from a felonious assault by liquor elements, fatally wounded his principal assailant; arraigned for the deed in the criminal courts he was promptly acquitted on the grounds of self defense, and was continued in good standing in the conference until he saw fit to transfer elsewhere.

\section{Lay Delegates Seated With Clergy}

The invitation extended in 1872 for lay attendance on the next years session was accepted by five of the six districts, whose fifteen delegates were seated with the clergy and granted the privileges of debate and of voting on all but constitutional questions. It is not of record that any of them sat in with the bishop and cabinet, nor is it likely that they did. The invitation was never renewed, although in 1879 the Lay Electoral conference asked that it might be, and petitioned General conference for legislation making this the law of the church, of which nothing resulted. The Lay conference in 1887, of which body the writer was one, passed resolutions asking for legislation admitting women to the ministry, and giving equal lay representation in conferences and cabinets, neither of which objectives were achieved. But the rising tide of liberalism so flooded the General Conference of 1892 with demands for the admission of women that only by the parliamentary skill of the Rev. James M. Buckley, giant leader of the conservatives throughout the entire controversy, was the question sidetracked in committee, to the wrath of the liberal element, who in retaliation, sprung and passed over strenuous protests, in the closing moments of the session, a measure proposing that unless the church voted the word "male" into the qualifications, the constitution should be interpreted as admitting women as lay delegates; a move invalidated by the lack 
of a legal quorum in the count vote taken. However, public feeling and conviction had mounted to such a pitch, that in 1896 two amendments to church law were enacted, and approved, whereby equal lay representation was finally secured, without sex distinction, being first applied in the General conference of 1900, and Dr. Buckley gracefully expressed conservative sentiment by saying that despite the innovation, the Methodist Episcopal church was still the best church on earth! It was not for another generation however that lay men and women sat on equal terms with the ministry in the annual conferences.

The slackening revival interest deplored in 1872 was succeeded by seasons of spiritual refreshing, stemming in part from the vast Moody and Sankey evangelistic campaigns in the great cities, that with brief intermissions, continued well into the present century, resulting in material and numerical expansions best demonstrated by exhibits that may be compared with that for 1872 already given. Four years subsequently the statistics reported 19,914 laymembers, served by 138 pastors, whose salaries averaged $\$ 550.00 ; 160$ church buildings, valued at $\$ 437,394.00$; and benevolent collections almost double those of the former year. The 1884 records show 25,873 lay members and 164 effective ministers; 155 pastoral charges possessing 243 churches and 128 parsonages, worth $\$ 719,428.00 ;, 349$ Sunday schools enrolled 28,594 attendants; the benevolent offering totaling $\$ 13,172.99$; and 1,878 adult baptisms evidenced the vigor of soulwinning operations. Corresponding figures for 1892 give 40,062 laymembers, 180 effective ministers; 190 parishes with 395 churches and 158 parsonages, valued at $\$ 1,166,945.00 ; 432$ Sunday schools having 41,277 attendants' benevolent offerings, $\$ 32,272.00$; and adults baptized, 1,973. At the century end, there were 200 effective ministers and 208 pastoral charges; 465 Sunday schools enrolling 48,251; churches 448 ; parsonages, 187 ; combined value $\$ 1,498,699.00$; benevolent collections, $\$ 55,368.00$, a little over a dollar per member, of whom 
there were 51,666 , a net increase during the year of 1,827 , while 2,412 adult baptisms show that showers of spiritual blessing were falling all over the Des Moines Conferences.

Breaking down the number of parishes by areas, thirteen were located in three cities; eight in Des Moines, three in Council Bluffs and two in Boone; the remaining one hundred and ninety five being distributed evenly through the rest of the territory at the rate of about seven parishes to the county, with a sufficient number of preaching places on the circuits to average one per township; some indeed contained more than their share. Warren county boasted one township with four Methodist churches, two and three were not rare; while even in regions so occupied by European colonies that American congregations were nonexistent, the German, Swedish and Norwegian conferences-whose records are not available-maintained numerous missions; so that it can be safely said that there was hardly a spot within the bounds here considered where on Sunday one would be more than an hour's buggy ride from a Methodist place of worship.

That increased church support attended growth is manifest from the 1900 ministerial budget of $\$ 172,352.00$, something over $\$ 850.00$ per pastor; but amounts paid varied with size and means of congregations. First church, Des Moines, gave its pastor $\$ 2,400.00$ per annum; five others ranged from $\$ 1,300.00$ to $\$ 1,550.00$; nine were in the $\$ 1,200.00$ bracket; twenty-three ran from $\$ 1,000.00$ to $\$ 1,500.00$; seventy-nine from $\$ 700.00$ to $\$ 975.00$; sixty-two were between $\$ 500.00$ and $\$ 675.00$; of the twenty-two preachers receiving less than $\$ 500.00$ several were student pastors, some were retired ministers doing a species of home missionary work in fields adjacent to

\footnotetext{
"In Methodist terminology "Effective" ministers are members of conference subject to annual appointment; but the term does not include such supernumerary. retired or local preachers as may volunteer to supply vacant parishes, or remain unemployed at their option. Since almost- every circuit maintained Sunday schools at all of its preaching places, the difference in schools and church buildings as given in statistical columns indicates how many classes held services in public school houses or other buildings. Adult baptism was usually bestowed upon the reception of probationers into full membership in the church, and the number of such is fairly indicative of church growth during the preceding twelve months, after deduction of deaths and removals.
} 
their homes, and others were devoted local preachers, who, as in earlier days, earned most of their living in secular occupations. One unique case was that of a pastor who was promised only $\$ 350.00$ at the years beginning, reported $\$ 650.00$ paid at its end; evidently an instance of wearing better than expected.

\section{ADVENT OF REVIVALS}

The revival activities were originally carried on through the winters by the pastors, ably assisted by the presiding elders as they made their regular district rounds. Sometimes but rarely, neighboring ministers in "protracted efforts" exchanged work, like farmers in harvest; while in summer, camp meetings in which several contiguous parishes co-operated, promoted both social and spiritual welfare. As commodious church edifices multiplied, and farm labors grew more exacting, these latter gradually diminished in frequency; while as some ministers developed unusual talents as soul winners, almost unconsciously there evolved a class of specialists, who, taking the supernumerary relation, devoted themselves principally to revival work as they might be engaged by different churches. Most of these were willingly available as supplies for churches left pastorless by sickness, death or removal. Of such was the Rev. George H. Detwiler, safe, sane, spiritually and practically minded Des Moines conference product, who after much profitable labor here, going in search of a milder climate for his afflicted wife, with heartiest commendations, passed into the then Southern wing of Methodism. Such were gradually replaced by those engaged solely in conducting revival meetings, the fruits of which were left to be garnered by the pastor and staff of the church where held. Some were conscientious laborers, faithfully dealing with all comers, making themselves a blessing in any community; others for the publicity that would insure greater demand for their services elsewhere, swelled the numbers gained by so smoothing the way into the kingdom as to make their converts too often liabilities rather than assets; still others in pursuit of popularity 
relegated pastors to the sidelines to such an extent that the religious interest evoked by their magnetic presence, vanished with the smoke of the train bearing the evangelist to other scenes of triumph". And yet others there were who, flying off at tangents, intensively emphasized certain phases of Christian experience, proving their lack of what they claimed by virtually unchristianizing all who rejected their shibboleths, or questioned their interpretations; an intolerance that not unnaturally provoked resentments productive of private and public controversies that did neither church nor participants much good. That the cause of Christ prospered despite this abuse of the liberty of conscience is the best proof of its devine origin vouchsafed to the present age.

\section{GROWTH OF CONGREGational Conveniences}

Besides the increase in houses of worship most of the pioneer chapels eventually were enlarged or replaced by more pretentious structures. Probably not one of the parsonages occupied in 1872 continued in use at the end of this period, fortunately for the comfort and convenience of manse dwellers. Any outline of this program of improvements is omitted, although sufficient of primitive romance attended these adventures to justify recital of a couple of the more prominent. One of them occurred in Des Moines, where the overflow of the Fifth street congregation caused a portion, living in what was then the northwestern outskirts of the city, to form Centenary M.E. church, so named from its inception in 1866, during the one hundredth anniversary of American Methodism. Their modest meeting house was erected on Seventh street, close by the biggest brewery in Des Moines, whose habituees at times vied with the church goers, to the vast disgust of the very excellent line of ministers who served the flock for fifteen years; by which time the parent congregation, crowded out of the Fifth stréet location by

\footnotetext{
oStriking illustrations are afforded by two widely differing aftermaths of evangelistic campaigns; in one of 160 persons received on probation by the church where the meetings were held, all but three were received into full membership six months later. In the other instance, although the church records bore four or five hundred names as so received during the meetings, barely two percent were registered as becoming full members.
} 
encroaching business, also moved north and west, in such proximity to Centenary that the two merged at Ninth and Pleasant streets as the First M.E. church. The stately sanctuary reared on the site now covered by the KRNT Radio auditorium, figured for thirty years on the "Seven Steeples" postal card souvenirs of Des Moines. The Centenary church building, although nearly eighty years of age, still serves its generation as a remodeled dwelling house, while the rival booze factory was swept off the map by the state prohibitory law of 1883. A somewhat different tale relates that Council Bluffs Methodists upon outgrowing their primitive chapel, acquired for a new one the premises long defiled by the Ocean Wave saloon, most notorious vice resort from Chicago to San Francisco. From this vantage point Broadway church tower looks out where "All the roaring tides of life roll down in one long cataract" to the Douglas street crossing into Omaha. Local tradition has it that a boy who swept floors in that tabernacle of Satan until converted at the Methodist mourner's bench, and who finally became city missionary, was instrumental in securing that strategic site for a temple of God. If true, no other stars adorning his crown can dim the radiance of the one commemorating that achievement.

This general lengthening of cords and strengthening of stakes fostered not a little denominational pride in the participants, as displayed in presiding elder's reports. One of these boasted that in a given year the preachers of his district had delivered a round dozen of "first" sermons in upspringing villages on new railway lines; another registered five new churches per annum during his incumbancy; and a third in a district valedictory stated that while all other Protestant forces had erected fifteen churches within his bounds, he was leaving twenty-four more Methodist sanctuaries than he found.

The conference journal of $\mathbf{1 8 7 6}$ for the first time contained obituarial tributes to wives and widows of ministers, an improvement soon made a regular feature, too frequently consisting of merely stereotyped appreciations 
of the piety and sacrifices of the parsonage queens, but sometimes throwing informing sidelights on parsonage life. Another new departure marked the commencement of a reform, being resolutions censuring the use of tobacco by ministers, urging addicts to desist as an example to young men and a means of increasing their influence in the community; also proposing that future candidates for admission on trial be required to pledge total abstinence from the weed; a measure made into church law not many years afterward.

\section{Simpson College SuRvived}

This date likewise is an educational milestone, since through failure of all rival institutions Simpson Centenary college became sole purveyor of higher learning under the patronage of Des Moines conference. Owing to the almost total absence of graded and high schools in most of its area, the student body still consisted largely of grammar and preparatory classes, yet the liberal arts courses were slowly expanding and graduation classes increasing in personnel. Through the strenuous labors of financial agents, of whom perhaps George E. Griffith, of Indianola, was the most successful, endowment funds totalling $\$ 60,000.00$ had been accumulated. Unfortunately this principally consisted of estate and other long term interest bearing notes, the income from which was often affected by poor crops, low prices and consequent business depression, subjecting the faculty to frequent embarassment, while debts incurred in erection of buildings burdened the trustees continually; regardless of all which, Simpson was able to balance expense accounts with receipts so often as to be one of two Methodist schools in the United States able to claim that distinction.

About this time Simpson made an ambitious stab at university standing by establishing medical and law courses in Des Moines. Of the medical plan no more was heard, but the law class, on a self-supporting basis, was maintained for several years, under the tutelage of Justice William E. Miller, of the Iowa supreme court, being 
finally discontinued in 1880. This may have been one of numerous efforts to move the college bodily into the capital city, the most serious of which was broached in the Methodist state convention of 1881, in a proposal for an all-Iowa Methodist university, for which the three then existing colleges, reduced to seminary rank, should serve as feeders, a project snowed under by the active opposition of the friends of all three institutions. Under slightly different form the proposal was renewed in 1888 , in connection with the founding of Highland Park college, and defeated in the hottest conference debate to which this writer ever listened, only to come up the next year, backed by an offer of valuable properties on West Grand avenue that would have scarcely been refused, but a committee appointed to inspect the deal, found the sponsors unable to make good. Meantime, Simpson college, having shed in 1884 its cumbersome middle name, was putting forth the most strenuous exertions to fortify its position, and in so doing developed a genuine captain of finance, the Rev. Fletcher Brown.

In ten years of close association with the institution, first as financial agent and then as president, Dr. Brown lifted the millstone of debt from the necks of the trustees, placed a sightly group of buildings on the campus, boosted endowment funds both in quantity and productiveness, and advanced attendance until in 1900 Simpson college with unencumbered assets of $\$ 165,000.00$ and a student body of more than five hundred was placed firmly on the Iowa educational map. Moreover, through all the long drawn out struggles, high spiritual atmosphere was maintained by almost annual revivals that sent a continuous stream of recruits into the ministerial and missionary ranks, while excellent instructors drew thither knowledge seekers from far and near.

Then came a slender orphan youth, the very best Sunday school teacher old Bethel down in Ringgold ever produced, who by teaching school and by other occupations, including a term as county superintendent, in eleven years of hard work and study attained his A.B. 
Afterwards he filled college professor-ships; entered politics as private secretary to a Nebraska governor; went to congress for several terms; filled a responsible U.S. treasury post, and so ended his career. All through his sojourn in the national capital, the William E. Andrews home was one of few social centers whose guests were never tempted with wine or gambling devices.

Hither also came to his father's Alma Mater, Brenton $T$. Badley from faraway India, acquiring here the culture that elevated him to the episcopacy from which he so recently has been retired by reason of age. Beneath those maple shades Takesha Ukai received the training that placed him in the forefront of Japanese Methodism, as builder of churches and founder of colleges.

Here also when the black cloud of color prejudice eclipsed it elsewhere, rose the star of George W. Carver, wizard genius at unearthing God's treasures for needy humanity stored in the humblest forms of plant life $\mathrm{e}^{\tau}$. May present plans be speedily realized, and the George W. Carver Memorial hall rise in perpetual commemoration of that greatest Simpsonian of them all!

\section{Aid FOR Aged Ministers AND Their Widows}

The Preacher's Aid society, incorporated in 1872, functioned for over twenty years as a death benefit association, paying with surprising regularity its $\$ 500.00$ to each bereaved family of deceased ministers, until multiplying deaths from old age, and failure to interest younger clergymen in the plan, compelled reorganization by which the death benefit and annual dues features were eliminated and the membership expanded to include the entire conference roll. Then a more strenuous effort was put forth to build up the endowment which by the year 1886, chiefly through the earnest efforts of the Rev. Daniel McIntyre as field agent, and the careful

\footnotetext{
TAmong the snapshots in Memories Gallery of Fame are two of George W. Carver. The first registers a peep across his shoulder at the drawing lesson the negro lad was sweating over in a Simpson art class; the other is of his stately presence in the Indianola Methodist pulpit, as he delivered the Simpson baccalaureate sermon a year or so prior to his promotion to "Such great offices suit the full grown energies of Heaven." (Tennyson, "In Memoriam.")
} 
shepherding of the treasurer, the Rev. W. S. Hooker, had reached a total of $\$ 10,000.00$, after which the interest earnings were available to supplement the annual collections for conference claimants, yielding the initial year $\$ 771.00$ for that purpose.

It may be inquired why were the preachers so lacking in self interest as to allow so long a time to elapse from its inception before this enterprise could be placed on this basis? Because they were so constituted that, while throwing themselves with almost fanatical energy into money raising for churches, colleges, missions, charities and other worthy causes, self interest sounded so much like selfishness, that even erecting and properly furnishing parsonages commanded far less zeal than those other demands, and even their modest salary claims were oft times pressed with an apologetic air; while as to the distant future needs of themselves or their familieswell, kind Providence would look after such matters when the needs arose. And this spirit of inattention extended to those already in need, through death or advanced age, so that the collections for that purpose were never urged strongly enough to make the receipts keep proper pace with increases in salaries paid to those still active. Thus, in 1872 the $\$ 600.00$ divided equally among three widows grew so slightly that there were but $\$ 950.00$ to share among ten claimants in 1876, and in 1880 with six widows, and seven aged ministers, all of whom probably had wives, only one received an allowance of $\$ 200.00$, for there was but $\$ 1,260.00$ for the bakers' dozen, several of whom were granted but fifty dollars for the entire year's budget of expenses.

Up to the year 1877 the only receipts so used aside from conference collections were grants of $\$ 25.00$ to $\$ 35.00$ per annum from what was known as the Chartered Fund, established in primitive times, from which each annual conference received that amount, regardless of numbers or needs, but in that year another source of small returns came into being in the launching of the Daily Advocate, a four or eight-page sheet issued during the an- 
nual sessions giving full account of daily proceedings, religious services, sermons and lectures delivered and the ministerial appointments for the ensuing year, besides contributions from leading clergy and laymen concerning the history, doctrines and interests of the church at large. This publication circulating throughout the conference area conveyed valuable information and knowledge to all readers, and was such a popular advertising medium that besides serving its primary objective, meeting conference expenses and cost of publishing the annual journals, throughout its existence of thirty years or more, it regularly returned a profit of $\$ 74.00$ to $\$ 250.00$, which was always turned over to the Board of Stewards ${ }^{8}$. Even this pittance was eagerly welcomed, for it meant that one, two or maybe three individuals could be a little more.generously provided for.

With 1882 came still another outside lift when Book Concern profits were devoted to the support of conference claimants. These were allocated pro rata to the number of claimants and varied annually with the volume of business done by the denominational publishing house, the first subsidy to this conference being $\$ 230.00$, and towards the century end sometimes amounting to $\$ 2,000.00$ or a little more.

From all these sources there accrued in 1886 as follows: Chartered Fund, $\$ 30.00$; Conference Daily, $\$ 74.00$; Book Concern dividend, $\$ 265.00$; Preacher's Aid society, $\$ 771.36$; Conference collections, $\$ 1,417.37$; total $\$ 2,558$.73 ; distributed amongst twenty-two claimants as follows: One allowance of $\$ 235.00$; three of $\$ 200.00$; one of $\$ 173.00$; two of $\$ 150.00$; three of $\$ 125.00$; two of $\$ 110.00$; three of $\$ 100.00$; one of $\$ 75.00$; and six of $\$ 50.00$. And the very next year, although the stewards had almost five hundred dollars more at their command, there were five more needy claimants, and no one of the twenty-seven was allowed over $\$ 200.00$. Ten years subsequent to this the writer had his first glimpse of what later became his

\footnotetext{
${ }^{8}$ Until the creation of the office of Conference Statistician, the stewards prepared all reports of a financial nature. Afterward their work consisted solely of considering the claims and relieving the needs of conference claimants.
} 
principal church task, outside of parish duties, when with thirty-six retired ministers, most of them had wives, and twenty-eight widows, some with small children, the stewards had $\$ 5,678.46$ in hand, less than $\$ 100.00$ per case, and the highest awards were exactly the same as those of twenty-five years previous, although the cost of living was fully double, and pastors salaries greatly advanced. Nor' was the situation much bettered by 1900 , when for the first time an allowance of $\$ 250.00$ was made to one individual, for there were several who received but $\$ 25.00$.

Since all appeals to public generosity failed to stimulate church giving sufficiently to relieve these intolerable conditions, the Preachers Aid society resolved to increase its endowment fund far above its current standing, which in the fourteen years since it became productive had grown to $\$ 16,664.00$, yielding an income of $\$ 1,003.73$, with the certainty of lessening returns, since the trend toward lower interest rates, still in vogue, had already set in; so that loans once commanding eight to ten per cent produced but six and seven per cent. So, laying hands on the Rev. Fletcher Brown, who, after putting Simpson college on easy street, had returned to the pastorate, and with the pledge of a comfortable salary and reasonable travelling expenses, he was commissioned to launch a five-year campaign and add $\$ 50,000.00$ to the sum above named.

\section{Young People's Activity ENLARged}

No more spectacular and beneficial general church movement transpired in the period we are now considering than that which in Methodism evolved the Epworth League. Having its beginnings in young people's prayer meetings, formed to indoctrinate and establish the younger converts of the widespread revivals, this movement in time developed permanent societies of various names and objectives aimed to conserve and utilize the zeal and morale of these youthful believers; all of which were in the spring of 1889 blended in the one denominational 
organization, which was given official recognition by the General conference of 1892. The first mention of this new field of action occurs in the minutes of 1889 where Presiding Elder T. McK. Stuart of Corning district announced the formation of a district association of the recently combined young people's societies, for which he predicted great success and much accomplished. Similar reports in following years came from other districts, and in a remarkably short period there were Epworth Leagues in every pastoral charge, and generally at every preaching appointment. Indeed, in rural charges, the league was in many instances the only Sunday night service of any kind, taking the place of the vanishing class and prayer meetings, to a very large extent.

It was not until after 1900 that statistics for this branch of church work were inserted in the conference journals. So, for the present we content ourselves with the fact that during the two closing quadrenniums of the nineteenth century the senior and junior Epworth Leagues received as much attention from pastors and elder members of the church as did the Sunday school, and were of such relative importance that if the last named institution was properly considered to be the nursery of the church, the leagues were the training centers for all forms of religious activity.

$\checkmark$ One last forward step taken in Des Moines conference during this period remains to be mentioned. The hospital movement which found place in Methodist operations only a decade or two previously, had reached Omaha in the middle 1890's and was obtaining considerable support from Iowa Methodists adjacent to that city. About the same time Theodore Gatchell of Des Moines, an insurance executive, called the ministers and interested laymen of the city together at a dinner to discuss such an undertaking. In succeeding meetings a hospital association took shape with a suitable constitution and bylaws, and upon the offer for sale of the extinct Callanan Normal college plant, the Rev. John F. St. Clair was employed as financial agent to raise funds to buy and 
equip the building for its mission of healing. A committee report of these beginnings, with recommendations for adoption of the enterprise, passed the conference of 1899 unanimously; and articles of incorporation were framed. At the 1900 session it was reported that the property, worth $\$ 65,000.00$ had been purchased for $\$ 30,000.00$, and refitted for hospital use for $\$ 5,000.00$, to meet such expenses, $\$ 11,000.00$ had already been raised, and the institution ready for opening by November of that year. Certainly a splendid curtain raiser for the twentieth century.

\section{Ministerial Discipline}

Less pleasant is it to review the judicial procedure of Des Moines conference; procedure essential to sustain the denominational promise of "ministers blameless in life and conversation" for congregations having little choice of pastors, and less opportunity of making proper inquiry concerning them. Thus as the presiding bishop called each name on the roll propounding the required inquiry, "Is there anything against him?", if the response came "There are complaints against Brother disciplinary action must needs be instituted. These proceedings took form according to the nature of the offense; if charged with "maladministration" i.e. errors of judgement, or blunders in management, the culprit might remain in service and be referred to his presiding elder for investigation and report the next year, in which case, as a rule nothing more came of the matter, the irregularities being usually ironed out and adjusted among the parties concerned. Should it be a matter of indefinite statements of serious wrongdoing brought up for the first time in conference session, a special committee would be raised charged with the duty of inquiring whether they constituted grounds for trial. In such case further action would be taken, as in the instance of a minister charged with misconduct between conference sessions, who would be cited by his presiding elder before an investigating committee, who, in case the facts 
so warranted, would suspend him from the ministry until the ensuing conference, when the case would be tried by a select number, from whose verdict appeal could be made to a judicial conference, which body would confirm, reverse, or remand for a new hearing the findings of the lower body, as their best judgment might dictate.

Several such cases occurred, even in the earlier years 1860-72; the first being that of a charter member, who in 1863 was deposed from the ministry, but was partially reinstated in 1872 by restoration of parchments. In 1867 a conference probationer, convicted of some wrongdoing by the officiary of his circuit, appealed their verdict to annual conference, where the case was remanded for a new trial, and no further action of it appears, or of the accused. At the same session two conference members were expelled for gross immorality, one of whom disappeared, while the other, some years later, asked through another conference for restoration of parchments, on which no action seems to have been taken. '1870 witnessed the arraignment of two quite prominent clergymen, apparently in connection with land deals on the Dakota frontier. One was convicted, expelled and we hear no more of him; the other, though acquitted, withdrew from the ministry the following year, but still a year later asked for return of his credentials that he might enter the new North West Iowa conference. There he again fell under reproach, was expelled, drifted into atheism, of which he repented, again united with the church, and on being denied re-admission to the ministry, found welcome in a sister denomination, and we trust, in the better world.

Number" was composed of from nine to fifteen ministers of sopJuse posedly sound judgement and unprejudiced minds, who by conference vote. Some essiding elders, appointed by the bishop and confirmed by conference well as counsel pecially capable minister was in like manner assigned to prer cause, as was also the for the church, and all these were subject to challenge for cause, as wase against counsel for the defense, usually selected by himself. Howerer, when those for them, whom charges were pending were tried in absentia, counsel was appointed foc absence charged with protection of them from injustice, although the mere fact of absence might have been considered as prima facie confession of guilt. As the vict was powers of the conference were delegated to this body of men, their verdion in the final, if it was acquittal; but subject to appeal if conviction. As mentioned in the fext, trials of lay members for moral or legal causes were tried by lay committees of laymen, with appeal to the Annual conference, of which there.

the writer can recall but one such case in his entire experience. 
That the reconstructed Des Moines conference was equally zealous in keeping its record clean is evident from the thirty-nine cases of ministerial discipline occurring in the years 1873-1900. A number of these seem to have been regarded as of slight importance, since they were dismissed without trial as in two instances, several years apart, in each of which a presiding elder and one of his circuit preachers preferred. charges against one another. Whatever the merits of either case, the higher officials went on their way as before, while both circuit riders dropped out of the ranks. Several cases referred to presiding elders for investigation are mentioned no more, proving of little consequence or being settled out of court.

A certain supernumerary minister who engaged in secular business, was twice arraigned on charges of misconduct therein, was acquitted both times of intentional wrong-doing, but in the second instance was severely censured for careless methods and inaccurate account keeping. Another in the active relation, accused of dishonesty in a business transaction was likewise acquitted of unlawful intent, but sternly rebuked for irresponsible language and questionable behavior. Two, accused of imprudent conduct asked for and were granted locations rather than go to trial, one of whom while in that status did yeoman work in the Anti-Saloon League, and upon a retraction by the original complainants, was re-admitted and walked worthily to the end of his life.

The longest drawn out of all such cases was that of the minister already mentioned in these articles as guilty of illegal voting in the election of General conference delegates. He was arraigned, convicted and sentenced to suspension from the ministry for a year. On appeal he secured an order for rehearing; was convicted the second time and deposed from the ministry and again took an appeal, once more was granted a new trial, in which he brought charges of false testimony against the prosecuting witnesses, who after careful inquiry were exonerated, while the culprit was expelled from the ministry and membership of the church. Thirteen years subsequent 
to this last occurrence, he once more came before Des Moines conference with such confession and contrition as to win restoration of parchments and membership and a transfer elsewhere, and in the remaining years of his life there did the excellent work of which he had shown himself capable in the earlier days of his ministry.

Of clergymen brought to trial under church law, twelve were adjudged guiltless; four withdrew under charges; and fourteen were duly convicted-one of them twiceof which number eight were sentenced to expulsion, and six were suspended from the ministry for one year. Aside from the one experience given above, no appellant ever obtained a new trial, and in only two instances were sentences of the select number reversed; one of these undoubtedly was a miscarriage of justice, for by it a minister who had been convicted of imprudent and unchristian conduct and suspended for a year, was reinstated in good standing, and continued for a dozen years longer in leading pulpits, until confronted with complaints so well sustained that he did not even attempt a defense; and was finally expelled. In the other instance a grievous wrong was posthumously righted as far as might be by the court of appeals. A faithful minister, falsely accused of disgusting indecencies, through personal spite was expelled from the church, appealed the decision, but died of nervous prostration before the Judicial conference met. However his friends carried the case up to the next General conference which ordered a post mortem review of the case, in which the dead man's name was cleared of reproach, and his widow restored to her rightful place as a conference claimant.

The only arraignment of a member of this conference in the secular courts has been already mentioned in the pages relating to the temperance movement, and the verdict rendered was so universally approved by all rightminded people, that the only notice given it by the conference was to publish a calm and impartial review of the entire affair in the annual minutes. That some ungodly clergymen were permitted to avoid exposure by removing 
from among us was probably true, but the foregoing analysis as compared with the records of public administration of justice, will clear Des Moines conference of any suspicion of unfaithful dealing with its guilty members. Toward the century end less public modes of dealing with ministerial offenders began to obtain.

\section{VICTORIOUS IN LEADERSHIP}

An appraisal of ministerial accessions will close this section of our narrative, and since it would be impossible to fairly present all the hundreds of candidates received on trial or by transfer, selections herein of the best known and most prominent must suffice to sufficiently characterize the quality of all. Much of the leadership of this period has been already evaluated, calling for no repetition, while many entering the field within this era did not come into their own until after 1900, and must await future recognition for their laurels.

Two worthy brethren coming into the conference by transfer in 1873 made their mark in other than great churches. The Rev. Daniel McIntyre, from Indiana conference, gravitated into money raising, first for Simpson college, then for the Preacher's Aid society, both of which profited greatly from his exertions.

His just and discerning mind made him especially useful on trial committees and commissions handling difficult problems. To me his greatest service was contained in his farewell speech when asking retirement, he announced:

I am going home to Osceola to be a good superannuated Methodist preacher. I will attend church, class and prayer meetings and back up my pastor in every way $I$ can. If people come to me for weddings I will send them to him, and the only funeral sermon I will ever preach will be that of Father Wishard who led me to Christ in a Christmas eve revival when I was a 'teen aged boy.

Father McIntyre preceded his spiritual father to the grave; his knowledge of people failed him at the last, till he scarcely knew his own wife, but even amidst the shadows he knew Jesus Christ. 
The Rev. A. E. Thornbrue, born in Illinois, orphaned in infancy, converted at fifteen, and four years a soldier in the Union army, entered the ministry in 1868, joining the South Kansas conference on trial; was sidetracked three years by partial blindness, recovered, and was received into full membership by Des Moines conference in 1873. His widest parish was his last, the chaplaincy of Iowa Methodist hospital, but all service there or elsewhere was totally eclipsed on the day in Nevada, when he turned toward theology the face of a zealous law student who had just shown the spirit that was in him by going out in the cornfield and winning into his Sunday school class a tough, swearing plow-boy named "Billy" Sunday.

"Homer," said the pastor at Nevada, "God has something better for you than you will find in Fitchpatrick's law office; I want you to fill my appointment at the school house next Sunday afternoon, and see if you can find out what He wants you to do." The youth went and after his congregation were all gone, kneeled down and said, "Lord Jesus Christ, I'll do what you want me to do, and go wherever you send me!" That vow took Homer Stuntz to India, the Philippines, South America; made him missionary secretary and bishop of the Methodist Episcopal church; gave him eight splendid years of episcopal superintendency of the Omaha area-Iowa and Nebraska- "All this and Heaven too", where he and Asahel Thornbrue have long dwelt in loving fellowship.

\section{ONE Family's Marvelous Record}

The session of 1875 received on trial John, youngest of the Harned brothers, a trio of the type that inspire legends. A farmer in Marion county, he was followed the next year by his brother Michael R., a Civil war veteran of the 23rd Iowa infantry, and in 1877 they were joined by their oldest brother, William F.; a veteran of twenty-five years ministerial labor in Indiana, one of which was spent as army chaplain, and eight in two presiding elderships. His last parish there was what was 
known in conference dialect as a "One Man Church". The dominant individual in this. case shall remain nameless for the sake of the lasting benefits he conferred on the church by the right bestowal of his ill-earned wealth. In this charge the Rev. William F. Harned conducted a sweeping revival that brought over five hundred people into the fold, and here he waged successful war against the multi-millionaire boss, who vented his spite in veiled references to the approaching end of the conference year. "Brother .................," exclaimed the Quaker-born Methodist preacher, "I know exactly what you mean! You intend to see the bishop and presiding elder and tell them that I must move! Now I take great pleasure in telling you that I have consulted the bishops and presiding elders of both conferences and have arranged for a transfer to Iowa, where I will inhale a vastly more wholesome atmosphere than circulates around your money, much of which is badly in need of laundering."

Identical in spirit was the Rev. John Harned's reaction to the vainglorious camp meeting testimony of a parishioner, claiming the very highest attainments in grace possible for humanity. Going to the individual after the service, the pastor inquired, "Have you settled that business difference with your neighbor yet?" referring to a transaction having taken place some time previously. "No, and I'm not going to!" hotly retorted the individual. "Then never give that kind of a testimony again, for every body knows it isn't true."

The Rev. W. F. Harned spent eighteen out of twentyeight effective years in Iowa in or near Des Moines, and all in leading pulpits until time encroached upon his vigor. The younger brothers never climbed quite so high, perhaps because they started later in life, yet all were successful ministers of the word, efficient revivalists and faithful administrators of their parishes. Together they gave 116 years effective service in the ranks, and supplied feeble charges after retirement.

A nephew, the Rev. Alfred W. Harned, added thirtyfive years to the family record. They are chiefly re- 
membered however for the inexhaustible store of fun, bubbling out in most unpredictable ways, and frequently at one another's expense, as when "Mike" was assisting John in a protracted meeting was asked to say grace at the Friday dinner, the piece de resistance being the scant remnants of a huge pork roast, on which they had been feeding ever since Sunday. Without a word, Mike seized the platter, strode to the window, dumped its contents into the yard, sat down and profferred the customary devotions. "Brother Michael," protested John mildly, "Just why did you do that?" "Because I couldn't return thanks again for that same old hambone without lying," was the tart rejoinder.

While serving a pastorate in his home town of Columbia, John purchased a furniture stock which included the undertaking equipment for the community. Whereupon he wrote to a very particular ministerial chum: "Tell the brethren that I will bury them all with the greatest of pleasure, at the very lowest cost I can afford, excepting yourself and and (naming two especially intimate friends) whom I expect to charge all the traffic will bear." Called to a burial in a neglected mining community, John Harned, moved with compassion toward those for whose souls no man seemed to care, started preaching there, held a revival, organized the converts into a church, and secured the erection of a neat chapel, which has served that community a whole generation since the founder was taken to his reward. Would you hear more of these tales go over into Marion county, around Columbia and Attica, where their kith and kin abound, and the Harned lore and legend flourishes luxuriously.

Admitted on trial with John Harned in ministerial service came the Rev. Dinsmore Austin, well trained by several pastorates in New Hampshire, and some years of supply work in northern Iowa, where he became known as a strong arm champion of temperance, having by his massive frame and personal valor rescued a brother minister from the hands of drunken lynchers. Austin made 
his way into the more important grade of parishes by force of able preaching, plus an overflowing geniality that moved a non-church goer to remark, "That man's laugh is worth five hundred dollars a year to this community," although there is no record that any fraction of said $\$ 500.00$ accrued from that source. Ponderously obese in frame, black-bearded and eyebrowed, full and ruddy cheeked, one who saw him for the first time exclaimed, "Why I'd take that man for a saloon keeper rather than a preacher!" Passing to his reward one day preceding the opening of conference in his home town, Jefferson, he was given the only conference funeral of our history, conducted by Bishop Hamilton, assisted by the most notable ministers of our number, and the entire ministerial body walked as mourners behind his casket to the cemetery.

Among twelve admissions on trial in 1878 were the Rev. DeWitt C. Franklin, and the Rev. Augustine W. Armstrong. The former, the last accession to the "Continuing Cabinet" was tall and massive, pontifical in appearance and bearing, although gifted with a gamesome wit that on one occasion floored even Michael R. Harned of whom Franklin borrowed two pennies to buy a postage stamp, and promptly forgot all about it. A month or so passed, and Dr. Franklin received a bulky envelope, endorsed, "Postage Due, 2 Cents", filled with page after page closely written on both sides with reminders, remonstrances, reproofs, and tearful pleadings for immediate payment of said loan, direfully portraying the distressful plight impending over the lender in case of failure to comply. Two days later Harned was notified that a C.O.D. package was awaiting him at the express office, hurried thither, handed over his quarter, and hastened home, speculating as to what kind friend had remembered him thusly. Unwrapping the gift, he found a large shoe box, its contents swathed in covering after covering until the floor was filled with waste papers. At the very core of the wrappings neatly folded in tissue paper, was an old 
fashioned two-cent piece nearly as large as a silver quarter dollar, accompanied by a note demanding a receipt in full! Endowed with ability and attractiveness, Dr. Franklin stepped up from grade. to grade for twelve years, was appointed to Atlantic district, which he administered effectively for six years and then without an intermission went to Council Bluffs district for another full term in the sub-episcopacy. Making his first round of the new field, he encountered Father Hayes, pastor of a large. Catholic parish in Fremont county: "And so you are the new M.E. presiding elder?" queried the priest. "You are not nearly so venerable an appearing person as your predecessor, Dr. Hooker?" Replied the clergyman: "No, but I hope I am fully as religious a man." "That may be, Dr. Franklin," rejoined the Irishman, "But it is well to remember that "Flesh and blood doth not inherit the kingdom'," and the portly elder hadn't a word to say for himself! Closing these twelve years of district work Dr. Franklin transferred west, and, as I recall, served another district term and two or three prominent pastorates in Columbia river conference, then dropped down the coast and spent his retirement days in Los Angeles, among a large group of former Iowa co-laborers.

The Rev. A. W. Armstrong attained fame as an artistic secretary and competent historian; devoting himself too exclusively to these clerical tasks for satisfactory pastoral labors. People called him indolent, sometimes using a less polite term; but one cannot survey the mass of material he left, the accurately kept biographical records of every Methodist preacher who ever trod Iowa soil from Barton Randle to the latest admission on trial, all brought up to date shortly preceding his decease, and all neatly docketed in script plain as print, without exclaiming: "How on earth could one man find time to do all this?" Moreover, from his facile typewriter issued a number of copies of a manuscript history of Des Moines conference that never reached publication, and accumulations of all sorts, collected from conference journals, church per- 
iodicals, local newspapers, and tireless correspondence, intended as source material for a monumental history of Iowa and Dakota Methodism, the whole forming a mass sufficient for an ordinary lifetime task of digesting and properly arranging. There are studies for a partially completed Biography of the M.E. Bishops, a library numbering thousands of volumes, and at least two tons of manuscript sermons, lectures, newspaper files, etc., that went into the waste paper drives; proving our contention that A. W. Armstrong, whatever else he might have been, was not lazy. Left alone by the decease of his companion, his mind became clouded in the later years; returning to his lonely home at a late hour from his last conference session, he collapsed completely, and a Presbyterian minister living nearby found him at sunrise pacing the alley while preaching to unseen congregations. The hastily summoned physician surprised him at the telephone trying to arrange with Ohio parties for the burial of a brother who had passed away several years previously. That final relief from such conditions came speedily was no occasion of sorrow to anyone, and it will be many a long year before we look upon his like in his peculiar field of interest.

Dr. Fletcher Brown joined in the Class of 1879, and to him his farmer father said, "My boy, if you are going to be a preacher you'll never have a dollar! So I am going to save up something for you when your parents don't need it any longer." Himself no wastral Fletcher Brown by the care of the competence thus provided acquired the business experience needed for the money raising career that opened before him.

1880 brought in the Rev. Edmund M. Holmes, son of a pioneer presiding elder, and himself destined to the same rank for nine years, three on Boone and six on Des Moines districts, prior to which Simpson college board of trustees made him the youngest college president in the United States, save for a precocious youth named William A. Quayle, down in Kansas. 
Also in 1880 the Rev. EImer W. McDade, fresh from a Maryland college, entered upon a ministry that likewise led up to district supervision, but better still, developed a measure of pulpit power that kept him usually in his parishes for the full pastoral term until the time limit was removed. Both these men contributed heirs to their ministerial estates; Dr. Merrill J. Holmes has long filled essential official positions with great acceptance, and both of the younger McDades are useful ministers of the word; the elder, itinerating on a wider scale than ordinary has filled pastorates in three states, and served districts in two different conferences. A third name in that class was that of the Rev. George M. Jeffrey, who, devoted to a missionary career, went first to South America with William Taylor's self supporting work; then spent hard and anxious years in Utah during the polygamous regime of Mormonism; and in the infancy of Methodist ministrations to the afflicted was field agent for Chicago hospital.

There were two Williams in the class of 1881, one of whom, surnamed Shipman, alive with crusading zeal, as an Audubon county dry leader, waged successful battle against the forces that had introduced the infamous "Mulct Law" compromise with iniquity into thirty-nine Iowa counties, but never gained another after that defeat. Later on this brother felt called upon to chastise what he considered a letting down of moral standards in conference membership, using methods that made him something of a thorn in the flesh, yet served to maintain principles of rectitude among us. The other William, Stevenson by name, Irish born, bred and blunt, came from the carpenter's bench and moved up from an obscure charge, where he built his own parsonage, to ever more prominent places, and several conference interests as statistician and secretary, until the presiding eldership opened for him; after which, along with his layman brother John, was active on the board of stewards; the layman until death, and William as treasurer for eight years after retirement terminated his member-ship on the board. 


\section{THREE EXCEPTIONAL LEADERS}

If presiding eldership constitutes greatness, three such "greats" presented themselves on trial in 1882, all three possessing elements of superior quality, aside from mere official distinction. These were the Reverends William B. Thompson, James H. Senseney and Amos E. Griffith. The three had much in common; all were blessed with appreciative, useful and devoutly minded wives; all with force of pulpit and pastoral ability above the ordinary had ministered to a number of the foremost churches in the conference, of which Wesley church, Des Moines was the most prominent, where they served terms in close sequence. All three sat in the General conference of 1904, Thompson at the head of the conference delegation and the others as alternates. They were in the cabinet together, superintending respectively, Thompson the Chariton, Senseney the Des Moines and Griffith the Council Bluffs districts. The two former bore the reputation of depths and heights of spiritual attainment, so graciously presented and so coupled with hard study and persistent application to pastoral duties as to overcome the handicap of limited youthful educational privileges, sufficiently to carry them from minor rural circuits to the levels already mentioned. While not yet advanced in age they died within four months of each other, after long and painful illnesses. Entering the ministry with a college degree, Dr. Griffith began in a first-class appointment and held his own steadily; as truly religious as his classmates, his chief asset was a calm suavity of spirit that carried him successfully through a musical eruption in one of his leading parishes, so virulent that it got into the Chicago dailies. As his principal contributions to conference prosperity and growth were made in the present century, we defer full appraisal until later.

The Reverends Joseph B. Harris, Lewis B. Wickersham, William G. Hohenshelt and Elmer E. Ilgenfritz of the class of 1883 distinguished themselves in various ways, but first of all by continuity of pastoral service. 
Six years after their admission on trial, this writer listened in enviously on their discussion of the two full terms, under the three year rule, they were then completing; and, as the five year regime was then in vogue, they all went in on that just as a matter of course. Harris, cadaverous in face, frail in physique and health, died first of the group. He served several first class churches, and was for a while president of Simpson college; of which institution Wickersham was field agent for several years. Then Harris slipped into the Chautauqua system, and finally over the unanimous protest of the conference, asked for a location that he might devote himself to the lecture platform. The other two attained district rank, returned to the pastorate after a full term each, and passed on, Ilgenfritz dying in the harness and Hohenshelt soon after retirement with broken health.

Two transfers of 1884 claim attention. The Rev. John F. St. Clair, from Indiana, was probably the ablest member of Des Moines conference who never was appointed to a district, nor elected to General conference, although fully capable of either responsibility. Of more value to the church and humanity than either distinction was the unknown number of conversions attending his regular Sabbath day services, and prouder monument than any office holding is the Hospital whose finances he first managed. Then he became financial assistant to Bishop Stuntz, in which capacity he dedicated churches, planned building campaigns, launched church budgets; but passing away in the midst of such labors.

The Rev. William W. Ramsey came from Kansas; colossal in form, although of but moderate ability either as preacher or administrator. He was appointed presiding elder of Boone district as it was rumored, because of his imposing appearance, by a bishop who was graciously favored by kind Providence in the same manner. After completing his term, when the Rev. W. T. Smith was elected missionary secretary, Dr. Ramsey was assigned to fill out his unexpired year on Creston district, and then placed on Atlantic district, from which he resigned after three 
years and took supernumerary relations to better care for an afflicted wife, who outlived him a quarter of a century.

1885 brought in as special transfer from Minneapolis to First church, Des Moines, Dr. Emory Miller, the deepest thinker and most powerful pulpit orator ever on our rolls. He. had already achieved distinction in Iowa, St. Louis, Upper Iowa and Minnesota conferences, to which he added fame as author of "The Evolution of Love", a work commanding the admiration of William E. Gladstone and other great British minds. So void was Dr. Miller of theatricalism, that when moving into Iowa City to assume the pastorate in that center of early Iowa culture, the family cow balked at following the wagon into the water, Dr. Miller, whom the petted creature would follow anywhere, led her across Iowa river, wading waist deep in the stream. As an executive both Dubuque and Des Moines districts prospered under his superintendency, even if the latter did suffer in personnel from the predatory tactics of more astute members of the "Continuing Cabinet" who suavely diverted preachers to other districts, while Dr. Miller was vainly looking up the standing of the exchanges proffered as replacements. Facing the men on the train after conference adjournment, the bereft presiding elder exclaimed, as he scanned a printed list of the appointments, "I will not say that there was a conspiracy between you two men to rob my district of its ablest preachers, but this list reads exactly as though there had been such a scheme ${ }^{10}$ !" Of generous instincts, and himself addicted to the discredited tobacco habit, Dr. Miller was a ready defense attorney for offending clergymen, and entirely too much given to harsh reflection upon the attitude of those whose sense of justice was more rigid than his own. Having enjoyed all honors save the very highest, that his denomination could bestow, at the last quadrennial election before his retirement, Dr. Miller withdrew his name from consideration as delegate to General conference, saying kindly to his

${ }^{10}$ This episode was related to the writer with considerable glee by one of the alleged "conspirators." 
friends, "I have had my day, and there are worthy younger men who can render abler service; thanking you all for the many favors heaped upon me in the past, please do not vote for me any more." Nor did he, if memory serves me aright, ever again participate in conference discussions.

The Rev. Albert H. Collins came from Missouri at the same time as did Dr. Miller. He was a plain hardworking pastor and earnest preacher of the Word. After a sufficient round of higher class pastorates he attained district rank; as did another transfer of the same year, who shall remain unnamed; a man of brilliant mind, sarcastic in thought and word, who while a presiding elder, fell under a moral and mental cloud, and ended his days in a tragic accident.

1889 should have brought in an accretion of talent, for eight transfers were received from areas dispersed from Arkansas to New York; but of the eight the Rev. Charles J. English alone achieved eminence, and that was in the more appreciative climate of his native Missouri. While of seven admitted on trial William A. Main was the only one deserving a halo, for as missionary, missionary superintendent, and college president, he made church history in China for half a lifetime; but Des Moines conference knew of him only as we read of him in the church papers. The least gifted preacher of the seven was the only district executive among us, and he served two districts, doing the job well. Four others tarried here more or less briefly, then sought more promising fields. Of the abilities of the seventh, the readers of these sketches can judge more impartially than the sole survivor of the group, who is here portraying the recollections of an epoch fast slipping away from human memory.

By way of compensation 1890 added two names of fair repute to our numbers, and started one to fame and eminence elsewhere. The Rev. Benjamin F. Miller and Reuben E. Shaw were able preachers and excellent district administrators, the latter serving two districts in this 
capacity. The Rev. John W. Robinson travelled a very minor circuit for one year, was then left without appointto attend school, and in 1892, was as a probationer of the second year transferred to the North India conference, where he came into his own, and we knew of his promotions as we read in the church papers, until after many years, at Indianola where he was received on trial. Bishop John W. Robinson of India (retired) greeted the few survivors of those who first welcomed him into our ranks.

Of half a dozen coming to us in the closing decade of the nineteenth century, who achieved district headship, only the Rev. Willis H. Cable is now living, and he with the others was not advanced to that position until after 1900 . We will dismiss the names of such others as joined us during those years with few exceptions as being "Good men and full of the Holy Ghost", adding that most of them now "rest from their labors and their works do follow them;" leaving the narrator lonely for the touch of vanished hands, and the sound of once familiar voices.

\section{Extension of Pastoral Terms}

There remains one marked modification of old time Methodist polity enacted during the epoch covered in this article that should be treated and its results noted. This was the extension of the pastoral term from three to five years, simultaneous with which the presiding eldership term was lengthened from four years to six. This change took place in 1888, and continued until 1900 , when the limit upon pastoral re-appointment to the same charge was abolished, without affecting the district term.

Reactions to the change of 1888 were first felt in the official life of Des Moines conference, three presiding elders whose terms were closing automatically being continued, and the six-year district term so regularly observed thereafter, that any curtailment was likely to occasion remark, and was sometimes attended by elaborate episcopal explanations. But it was not so with 
parish pastors, for of ten who were completing threeyear terms at that time, but one was re-appointed for the fourth year, the Rev. David Shenton, who was continued for the fifth year in a not very important parish. 1899 witnessed but two four-year appointments, both of which were also continued for the fifth.

Gaining a little favor the new regime produced five five-year appointments in 1891 and an equal number in 1892; there were six such in 1896 , but from then on they decreased until in 1900 , with the time limit abolished, but one preacher was assigned for a fifth year. It was not until 1906 did any charge in this conference seem to discover what had been done in 1900. The four-year appointments fared a little better, there being twelve such in 1895; but then a dwindle set in and in 1900 only three were so assigned. Altogether during the twelve years of the operation of the lengthened pastoral term, there were seventy-two four-year appointments, thirtyfive of which became five-year terms; three of these were repeats, that is three preachers enjoyed two such terms, leaving thirty-two ministers, less than one-sixth of our total number who attained that distinction. Of the thirty-seven four-year appointments, a few were filled by "five-year men" either before or after their full term records; so that in all considerably less than one-fourth of the conference membership experienced any benefit from the change. Indeed, rather the reverse, for whether preachers were seeking ideal parishes and parishes ideal pastors, or for some other cause, instead of the majority moving into the three-year bracket, as had been confidently predicted, the number of one-year pastorates multiplied until the situation closely resembled that of the primitive two-year pastoral limit when three-fourths of the ministers moved every year".

\footnotetext{
11During the years 1860-63; in western Iowa under the two-year. limit there were forty-one two-year pastorates, and one hundred and fifteen of a single year; at the close of the first year of the unlimited pastoral term the following pastoral terms were completed: one of five years; three of four; eighteen of three; seventy-three of two, and one handred and three of one year. Average period of service in same parish, 1863-7 one year, three months, six days; 1900-1901, one year, seven months.' sixteen days.
} 
Moreover, although the arguments favoring the time extension dwelt principally upon the hardship and injustice imposed upon ministers of outstanding abilities, and churches of great numbers and influence, in compelling them to dissolve partnership "when the clock struck three", so far was this from attending its operation in this conference that three humble local preacher "supplies" appeared among the thirty-two five-year men, to whom we may add a raw youth, just received on trial, who by his own admission went out with but one prepared sermon in his repertoire, going to a most difficult field, where a rival church, having a pastor likeminded with his flock, seemed to consider the coming of the totally inexperienced boy preacher, as affording a golden opportunity for sweeping the Methodist church clear off the $\mathrm{map}^{12}$. Of the twenty-eight other five-year pastors about equal numbers were in the highly-gifted middle class and less able ranks; and the parishes they served were as widely dispersed from the highest to the lowest grades as respects salaries paid and advantages offered their incumbants. Whether results similar to the foregoing featured this new departure elsewhere could only be determined by those familiar with conditions. This represents the reactions of the Des Moines conference to the change in denominational polity.

wSuch occurrences were rare, although denominational competition was keen in most places, the relations between members of various churches being cordial as a rule, and ministerial colleagues generally good friends. In this particular case the rival church was largely composed of former Methodists, most of whom had changed allegiance because of personal differences with associates; the church they joined was one of the largest of that denomination in the state, the pastor in consequence one of their ablest preachers. That the "boy preacher" was equal to the situation is evidenced by the five-year stay; with the further demonstration that when, after a few years interval the writer was appointed to that parish, the that when, after cooled off quite noticeably and the same minister proved a very agreeable ne ighbor. 
Copyright of Annals of Iowa is the property of State of Iowa, by \& through the State Historical Society of Iowa and its content may not be copied or emailed to multiple sites or posted to a listserv without the copyright holder's express written permission. However, users may print, download, or email articles for individual use. 